\title{
The Effect of Filler Type and Content on Hot Asphalt Concrete Mixtures Properties
}

Nathem A .H. AL- Saffar /Assistant Lecturer

College of Engineering / Civil Dept. Mosul University

\begin{abstract}
Asphalt concrete consists of coarse aggregates, fine aggregates, filler, and asphalt cement(used as a binder)mixed together in proportions according to a specified specifications.

Mineral filler is the inert material passing the No.200 sieve, occupies the void space between coarse aggregates particles and pores within the aggregates particles .There were many types of local waste materials that can be used successfully used as a mineral filler in hot asphalt concrete mixtures instead of ordinary portland cement and limestone powder.

The main objective of this research is to investigate experimentally the effect of using different types of fillers, and content, on hot asphalt concrete mixtures. Several specimens of hot asphalt mixtures were prepared according to (SORB/R9) using the obtained Optimum Asphalt Content (O.A.C.) with three percentages of the fillers of ordinary portland cement, lime stone powder, and waste glass powder at $4 \%, 6 \%$ and $8 \%$ by weight of total aggregates, respectively.

The results of Marshall tests on mix design of hot asphalt concrete mixtures, for the wearing course were concluded that, using the waste glass powder as a filler, with its optimum content of $8 \%$ (by the weight of total aggregates), leading to produce asphalt concrete mixtures with higher Marshall Stability, lower Flow, and lower voids in total mix comparing with ordinary portland cement and lime stone powder fillers.
\end{abstract}

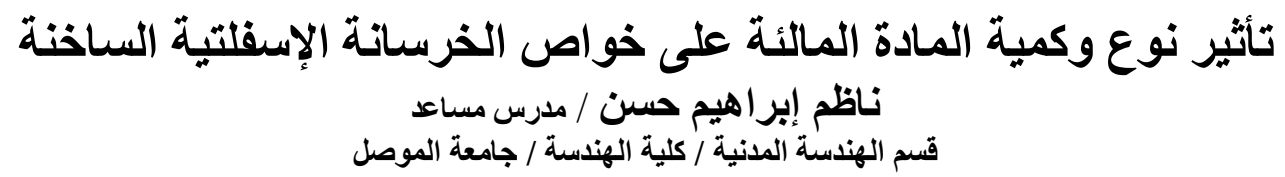

\section{الخلاصة}

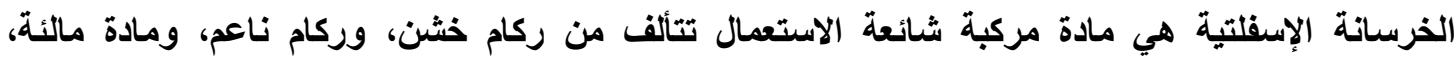

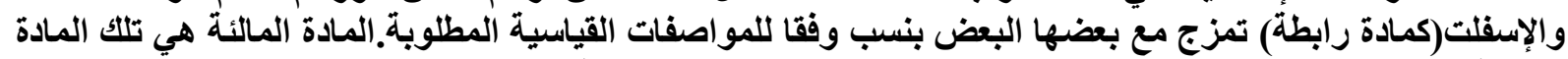

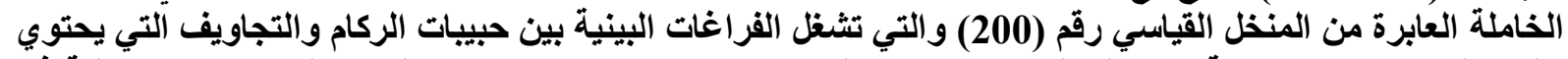

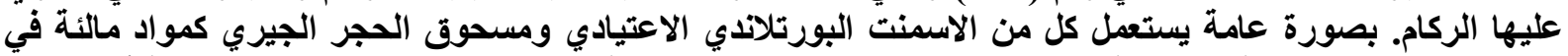

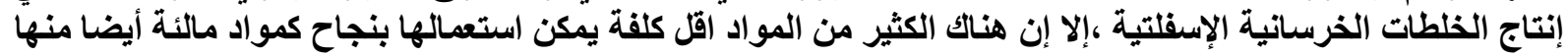

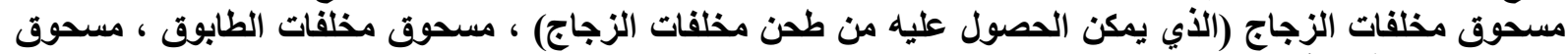

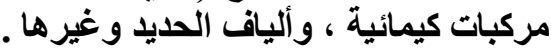
إن الهذف الرئيسي من هذه الاراسة المختبرية والنظرية بيان تأثير نوع وكمية المادة المالئة على خصائص المئية

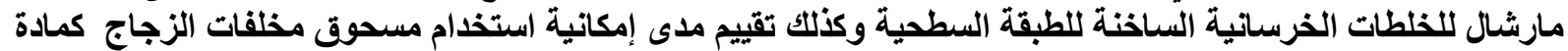

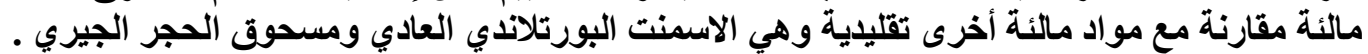

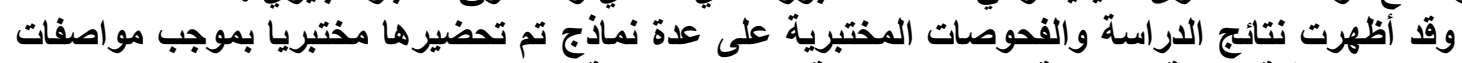

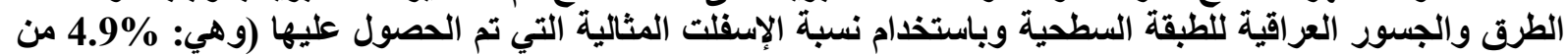

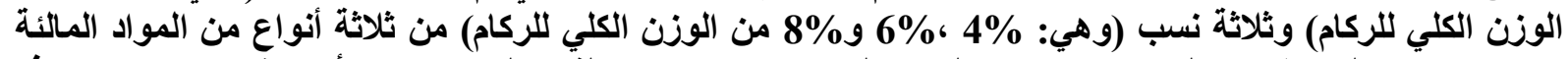

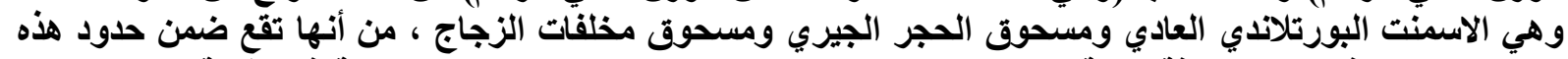

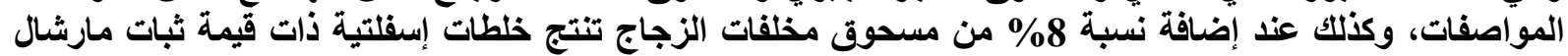

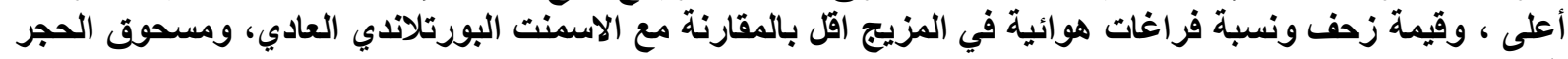

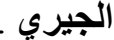




\section{Nomenclature:}

H.M.A: Hot Mixture Asphalt. $\quad$ O.A.C: Optimum Asphalt Content. V.F.A: Voids in mineral aggregates Filled with Asphalt. VTM: Air Voids in Total Mixture.

\section{Introduction:}

Asphalt mixes are used in the surface layer of road and airfield pavements. The mix is composed usually of aggregate and asphalt cements. Some types of asphalt mixes are also used in base course. The design of asphalt paving mix, as with the design of other engineering materials is largely a matter of selecting and proportioning constituent materials to obtain the desired properties in the finished pavement structure.

The term mineral filler is typically referred to the mineral fine particle with physical size passing the number 200 standard mesh sieve ( 75 micron). The use and the application of mineral filler in asphalt mixtures are intended to improve the properties of binder by reducing the binder's inherent temperature susceptibility [1]. Mineral fillers play a dual role in asphalt mixtures, first ; they act as a part of the mineral aggregate by filling the voids between the coarser particles in the mixtures and thereby strengthen the asphalt mixture, second ; when mixed with asphalt, fillers form mastic, a high-consistency binder or matrix that cements lager binder particles together; most likely a major portion of the filler remains suspended in the binder while a smaller portion becomes part of the load bearing framework [2]. The type and amount of filler used in hot asphalt mixtures would be affecting the properties of the mixes .The use of industrial and by - products wastes as replacement of mineral fillers in asphalt mixtures to enhance the properties and performance of asphalt concrete pavements ${ }^{(3)}$. An extensive programs of investigations have been carried out to evaluate the suitability of many types of mineral fillers to substitute the costly common fillers used such as ordinary portland cement and limestone powder, at mean while, there are many types of local waste materials (recycle) that can be used successfully as a mineral filler in hot asphalt concrete mixtures instead of ordinary portland cement and limestone powder such as waste of glass, ceramic, bricks.

The use of waste glass as mineral filler in hot asphalt mixtures for the construction of pavements has benefits in not only reducing the amount of waste materials requiring disposal but can construction materials with significant savings over new materials . The use of these materials can actually provide value to what was once a costly disposal problem.

The main objective of this research were to investigate experimentally the effect of using different types of fillers, and content which was ordinary portland cement, lime stone powder, and recycle glass powder in Marshall properties of hot asphalt concrete mixtures for wearing course. In addition to assess the suitability of the additive recycled glass powder as alternative mineral filler to other traditional fillers on Marshall Properties of hot asphalt concrete mixtures. So, Several specimens of hot asphalt mixtures were prepared according to State Organization of Roads, and Bridges Specifications (SORB/R9) [4] using the obtained optimum asphalt content (O.A.C) with three percentages of the fillers of ordinary portland cement, lime stone powder, and waste glass powder at $4 \%, 6 \%$ and $8 \%$ by weight of total aggregates, respectively.

The results of Marshall tests on mix design of hot asphalt concrete mixtures for the wearing course were concluded that, using the waste glass powder as a filler with its optimum content of $8 \%$ (by the weight of total aggregates) leading to produce asphalt concrete mixtures 
with higher Marshall Stability, lower Flow, and lower voids in total mix comparing with ordinary portland cement and lime stone powder fillers.

\section{Literature Survey:}

Many researchers such as, and Al-Sayed M.H. [5]carried out extensive research work on filler used in asphalt mixes. It is suggested here that substitution of the crushed limestone fines passing $(0.975 \mathrm{~mm})$ by a stronger, and cleaner filler would improve the properties of asphalt mixes and consequently, reduce rutting, swelling cracking and fretting of pavements surface.

Harrigan E.T [6] defines mineral filler as that certain mineral particle which were suspended in bitumen. They alter its consistency, and ultimately the character of the pavement. He considered that number (200) sieve can be used as the dividing line between filler, and aggregates particles. In general, fillers reduce the voids and increase the density, stability and toughness of the asphalt mixes. As filler content increases, the brittleness and tendency to crack in service also increase.

Two theories had been proposed by Csanyi L.H.[7] regarding the functions of fillers. The" Filler Theory "presumed that particles coated with bitumen fill the voids in the aggregates."Mastic Theory" proposed that the filler and bitumen combined to form mastic which fills the voids and binds the aggregates.

Al-Qaisi T.A. [8] studied the effect of filler type and proportions on the properties of filler-bitumen systems and bituminous paving mixtures. He investigated four types of fillers (Portland cement, limestone, dust, and powder of crushed gravel). He stated that the range of the filler-asphalt (F/A) ratio required to provide the desired properties of paving mixtures is influenced by the type of filler used.

Sofia G.G.[9] found that the use of collected dust fines to substitute ordinary fillers (used in Iraq such as portland cement, limestone dust, hydrated lime) gave a quite satisfactory results, i.e., in terms of stability values and other Marshall properties. Filler has a great influence on the adhesion, i.e., the asphalt-filler mastic is considered as a asphalt which has a viscosity higher than the asphalt alone, which improves the mechanical properties of asphalt mix. Furthermore, active fillers react with water to improve the physic-chemical properties at the interface of aggregates asphalt and reduce stripping.

Harris B.M. and Stuart K.D. [2] have conclude due to research works on filler used in asphalt mixes, that fillers play a dual role in asphalt mixtures, first ; they act as a part of the mineral aggregate by filling the voids between the coarser particles in the mixtures and thereby strengthen the asphalt mixture, second ; when mixed with asphalt, fillers form mastic ; a high - consistency binder or matrix that cements larger binder particles together; most likely a major portion of the filler remains suspended in the binder while a smaller portion becomes part of the load bearing framework .

Sadoon O.E. [10] studied the effect of different filler types on performance properties of asphalt paving, so six different types of filler are used to evaluate the resistance to plastic flow using Marshall Stiffness test and low temperature cracking and temperature susceptibly using indirect tensile strength test in addition to study retained strength test and resistance to permanent deformation by using indirect tensile creep test .The results indicate that filler type has a great effect on the cohesion of the mix where such types shows high indirect tensile strength values with respect to other types of filler at different test temperature 


\section{Raw Materials:}

The materials which were used in this study were all locally available as listed below:

\subsection{Asphalt Cement:}

Asphalt is the most commonly used material in pavement construction today because of its high engineering performance capabilities such as elasticity, adhesion and water resistance. Todays asphalt is produced mainly by the refining of crude oil and the physical and chemical properties can be altered or improved by blending, air blowing, additives etc. A petroleum asphalt grade 40/50 brought from Bagee Refinery was used in this research, Such grade is normally used in Roads construction projects in Iraq . The physical properties of asphalt were tested according to standard specifications and listed in Table (1) .

Table (1) Physical Properties of Asphalt Cement

\begin{tabular}{|c|c|c|c|c|}
\hline Properties & Unit & $\begin{array}{c}\text { Test } \\
\text { Specification }\end{array}$ & $\begin{array}{c}\text { Test } \\
\text { Results }\end{array}$ & $\begin{array}{c}\text { Specification } \\
\text { Limits } \\
\text { for } \\
\text { Grade } 40 / 50 \\
\end{array}$ \\
\hline Penetration at $25^{\circ} \mathrm{C}, 100 \mathrm{~g}, 5 \mathrm{sec}$. & $0.1 \mathrm{~mm}$ & ASTM D-5 & 44 & $40-50$ \\
\hline Specific Gravity at $25^{\circ} \mathrm{C}$ & - & ASTM D-70 & 1.04 & NA \\
\hline Softening Point (R. and B.) $5 \mathrm{C}^{\mathrm{o}} / \mathrm{min}$ & $\mathrm{C}^{\mathrm{O}}$ & ASTM D-36 & $57^{\circ} \mathrm{C}$ & $51-62$ \\
\hline Flash Point (Cleveland Open Cup) & $\mathrm{C}^{\mathrm{O}}$ & ASTM D-92 & 243 & $232 \mathrm{~min}$. \\
\hline Ductility at $\left.25^{\circ} \mathrm{C}, 5 \mathrm{~cm} / \mathrm{min}\right)$ & $\mathrm{cm}$ & AASHT D-113 & $>100$ & $100 \mathrm{~min}$. \\
\hline $\begin{array}{c}\text { Thin Film Oven Test: } \\
\text { Loss in mass } \\
\text { Related Penetration of original } \\
\text { Ductility at } 25^{\circ} \mathrm{C}, 100 \mathrm{~g}, 5 \mathrm{sec} .\end{array}$ & $\begin{array}{l}\% \\
\% \\
\mathrm{~cm}\end{array}$ & ASTM D-1754 & $\begin{array}{c}0.72 \\
59 \\
>25\end{array}$ & $\begin{array}{l}0.75 \text { max. } \\
55 \text { min. } \\
25 \text { min. }\end{array}$ \\
\hline
\end{tabular}

\section{2 Aggregates:}

Aggregate is a collective term for sand, gravel and crushed stone mineral material in their natural or processed state. Fine aggregate defined by (AASHTO M-147) [11] as natural or crushed sand passing the number 10 sieve and mineral particles passing the number 200 sieve .Coarse aggregate defined also by (AASHTO M-147) as hard, durable particles or fragments of stone, gravel or slag retained on the number10 sieve. Usually coarse aggregate has a toughness and abrasion resistance requirement.

The coarse and fine aggregates were separated to various sizes. The combined gradations of aggregates was chosen to approximately meet the job mix limits of the gradation which specified by the (SORB/R9) for dense graded paving mixtures of wearing coarse. Natural crushed coarse, and partly crushed fine aggregates which used in this research were brought from one of the hot mix plants of the Roads Directory of Mosul City. The crushing process done at the asphalt plant by mechanical crusher to obtain crushed gravel. The coarse and fine aggregates were sieved and recombined in laboratory in order to produce identical controlled gradation and to meet the selected gradation which is shown in Table (2). The physical properties of this aggregates were shown in Table (3). 
Table (2) Specifications of Selected Aggregates for Wearing course

\begin{tabular}{|c|c|c|c|c|c|}
\hline \multirow{2}{*}{\multicolumn{2}{|c|}{ Sieve Size }} & \multicolumn{4}{|c|}{ Percent by Passing Weight } \\
\hline & & \multirow{2}{*}{$\begin{array}{l}\text { Job Mix } \\
\text { limits }\end{array}$} & \multirow{2}{*}{$\begin{array}{c}\text { Average } \\
\text { Job Mix } \\
\text { limits }\end{array}$} & \multirow{2}{*}{$\begin{array}{c}\text { Specification } \\
\text { Limits of } \\
\text { SORB / R9 } \\
\text { Wearing Course }\end{array}$} & \multirow{2}{*}{$\begin{array}{c}\text { Average } \\
\text { Specification } \\
\text { Limits of } \\
\text { SORB / R9 }\end{array}$} \\
\hline Inch & $\mathbf{m m}$ & & & & \\
\hline $3 / 4 "$ & 19 & 100 & 100 & 100 & 100 \\
\hline $1 / 2^{\prime \prime}$ & 12.5 & $87.1-99.1$ & 93.1 & $90-100$ & 95 \\
\hline $3 / 8 "$ & 9.0 & $74.1-86.1$ & 80.1 & $76-90$ & 83 \\
\hline No.4 & 4.75 & $46.7-58.7$ & 52.7 & $44-74$ & 59 \\
\hline No. 8 & 2.36 & $33.2-41.2$ & 37.2 & $28-58$ & 43 \\
\hline No.50 & 0.3 & $11.8-19.8$ & 15.8 & $5-21$ & 13 \\
\hline N o. 200 & 0.075 & $5.7-9.7$ & 7.7 & $4-10$ & 7 \\
\hline \multicolumn{2}{|c|}{$\begin{array}{l}\text { Asphalt cement (\% by } \\
\text { weight of total aggregates }\end{array}$} & $4-6$ & & $4-6$ & \\
\hline
\end{tabular}

Table (3) Physical Properties of Aggregates

\begin{tabular}{|l|c|c|c|}
\hline $\begin{array}{l}\text { Aggregates } \\
\text { Type }\end{array}$ & $\begin{array}{l}\text { Specific } \\
\text { Gravity } \\
\text { gm/ cm }\end{array}$ & $\begin{array}{c}\text { L.A. Abrasion } \\
\text { (AASHTO T 96) }\end{array}$ & $\begin{array}{c}\text { percent of } \\
\text { Water } \\
\text { Absorption }\end{array}$ \\
\hline $\begin{array}{l}\text { Crushed Coarse Aggregates } \\
\text { (ASTM D-692) }\end{array}$ & 2.63 & 17.3 & 0.43 \\
\hline $\begin{array}{l}\text { Crushed Fine Aggregates } \\
\text { (ASTM D-1073) }\end{array}$ & 2.68 & 20.1 & 0.62 \\
\hline
\end{tabular}

\subsection{Mineral Filler:}

Defined by the Asphalt Institute as a finely divided mineral product at least $65 \%$ of which will ass through a number 200 sieve. Pulverized limestone is the most commonly manufactured mineral filler, although other stone dust, silica, hydrated lime, ordinary portland cement and certain natural deposits of finely divided mineral matter are used [12].

Recycled glass powder is waste glass turned into usable products. Glass waste is separated by chemical composition, and then, depending on the end use and local processing capabilities, might also have to be separated into different colors.

Three types of mineral fillers have been used in this research those were: ordinary portland cement, lime stone powder, and recycle glass powder. The physical properties for these mineral fillers were shown in Table (4).

Table (4) Physical Properties of the Mineral Fillers

\begin{tabular}{|l|c|c|}
\hline Filler & Specific Gravity & \% passing sieve No.200 (0.075 mm) \\
\hline Portland Cement & 3.15 & 96 \\
\hline Lime Stone Powder & 2.78 & 94 \\
\hline Glass Powder & 2.65 & 92 \\
\hline
\end{tabular}




\section{Preparation and Testing of Marshall Specimens:}

\subsection{Marshall Method of Mix Design:}

The design of asphalt paving mix was largely a mater of selecting and proportioning constituent materials to obtain the desired properties in the finished pavement structure.

In Marshal Method, the resistance to plastic deformation of compacted cylindrical specimen of asphalts mixture is measured when the specimen is loaded diametrically at a deformation rate of (50) $\mathrm{mm}$ per minute. The Marshall stability of the mix is defined as the maximum load carried by the test specimen at a standard test temperature of $60{ }^{\circ} \mathrm{C}$.

The flow value was the deformation that the test specimen undergoes during loading up to the maximum load. Flow was measured in ( 0.25) $\mathrm{mm}$ units with rate of loading 0.05 in /min, in this test, an attempt was made to obtain optimum asphalt content for the type of aggregates mix used and the expected traffic intensity.

\subsection{Procedure of Marshall Method of Mix Design:}

In the Marshall Test method of mix design three compacted specimens were prepared according to (ASTM D 1559) [13] for each asphalt content. At least four asphalt contents were to be tested to get the optimum asphalt content (O.A.C) .All the compacted specimens were subjected to the bulk specific gravity (density) determination, stability, and flow tests.

The coarse aggregates, fine aggregates, and filler material were proportioned so as to fulfill the requirements of the relevant standards as shown in Table (2). The required quantity of the mix was taken so as to produce compacted asphalt mix specimens of $63.5 \mathrm{~mm}$ thickness approximately (1200) gm. of aggregates and filler were required to produce the desired thickness. The aggregates were heated to a temperature of 175 to $190^{\circ} \mathrm{C}$, the compaction cylindrical mould assembly $(10 \mathrm{~cm}$ diameter and $7.5 \mathrm{~cm}$ height consisting of a base plate and collar extension) and rammer were cleaned and kept pre-heated to a temperature of $100{ }^{\circ} \mathrm{C}$ to $145^{\circ} \mathrm{C}$. The asphalt was heated to a temperature of $121{ }^{\circ} \mathrm{C}$ to $138^{\circ} \mathrm{C}$ and the required amount of first trial of asphalt ( $4 \%$ by weight of total aggregates) was added to the heated aggregates and thoroughly mixed. The mix was placed in a mould and compacted with (75) number of blows . The specimen was taken out of the mould after few minutes using specimen extractor.

\subsection{Determining the Bulk Specific Gravity (Density) of the Compacted Specimen $\left(G_{m b}\right)$, theoretical Maximum Specific Gravity $\left(G_{m m}\right)$ of loose Asphalt Mixtures, and Bulk Specific Gravity of total aggregates $\left(G_{\mathrm{sb}}\right)$ :}

The bulk specific gravity (density) of the each compacted specimen $\left(\mathrm{G}_{\mathrm{mb}}\right)$ was determined according to (AASHTO T 166) by weighting the specimen in air and in water, and given by:

$\mathbf{G}_{\mathbf{m b}}=\frac{\mathrm{A}}{\mathrm{B}-\mathrm{C}}$

Where:

$A=$ Mass of dry specimen in air.

B $=$ SSD (Saturated Surface Dry) mass of the specimen.

$\mathrm{C}=$ Submerged mass of the specimen. 
The theoretical maximum specific gravity of the loose asphalt mixtures $\left(\mathrm{G}_{\mathrm{mm}}\right)$ was obtained according to (AASHTO T 209)' and given by:

$\mathbf{G}_{\mathbf{m m}}=\frac{\mathrm{A}}{\mathrm{A}+\mathrm{D}-\mathrm{E}}$

Where:

$\mathrm{A}=$ Mass of dry specimen in air

$\mathrm{D}=$ Mass of pycnometer filled with water at test temperature.

$\mathrm{E}=$ Mass of pycnometer filled with the specimen and water at test temperature [14] . equation:

The bulk specific gravities of total aggregates $\left(\mathrm{G}_{\mathrm{sb}}\right)$ obtained using the following

$$
\mathbf{G}_{\text {sb }}=\frac{100}{\frac{\text { Pca }}{\text { Gbca }}+\frac{\text { Pfa }}{\text { Gbfa }}+\frac{\text { Pmf }}{\text { Gbmf }}+\frac{\text { Pas }}{\text { Gas }}}
$$

Where:

Pca, Pfa, Pmf, Pas = the percentages by weight of ; coarse aggregates, fine aggregates, mineral filler, and asphalt content, respectively .

Gbca, Gbfa, Gbmf, Gas = the specific gravities of ; coarse aggregates , fine aggregates , mineral filler, and asphalt content, respectively [15].

\subsection{Calculations of the percent of Air Voids in Compacted Specimens (VTM, $V_{a}$, Voids Filled with Asphalt (VFA), Voids in Mineral Aggregates (VMA):}

The percentage of air voids in compacted specimen (VTM) is the ratio (expressed as a percentage) between the maximum theoretical specific gravity of the loose asphalt mixtures $\left(\mathrm{G}_{\mathrm{mm}}\right)$ and the bulk density of the each compacted specimen $\left(\mathrm{G}_{\mathrm{mb}}\right)$, and given by:

VTM, $\left(\mathbf{V}_{\mathrm{a})}=\frac{\mathrm{Gmm}-\mathrm{Gmb}}{\mathrm{Gmm}} \times 100\right.$

The percent voids in mineral aggregates (VMA) is the percentage of void spaces between the granular particles in the compacted paving mixture, including the air voids and the volume occupied by the effective asphalt content, and given by ;

VMA $=100-\frac{\text { G.mb } \times \text { Ps }}{\text { Gsb }}$

Where:

$\mathrm{G}_{\mathrm{sb}}=$ the bulk specific gravity for total aggregates.

Ps $=$ percent of aggregates by total weight of mixture.

The percent of air voids in mineral aggregates filled with asphalt (VFA) is the ratio (expressed as a percentage) between the volume of the air voids between the coated particles and the total volume of the mixture, and given by:

VFA $=\frac{\text { VMA }- \text { VTM }}{\text { VMA }} \times 100$

\subsection{Determination of Optimum Asphalt Content (O.A.C):}

The Marshall test results has been tabulated as shown in Table (5), and then Six separate smooth curves were drawn (Fig.1-6) Marshall Stability, Flow, Density $\left(G_{m b}\right)$, 
(VTM), (VMA), and (VFA). The optimum asphalt content was selected from Figures (1, 2, and 3$)$ as the average asphalt content for maximum density $\left(\mathrm{G}_{\mathrm{mb}}\right)$, maximum stability and the specified percent of voids in compacted mixtures $\left(\mathrm{V}_{\mathrm{a}}\right)$ [16]. Thus:

O.A.C $=\frac{\mathrm{A} 1+\mathrm{A} 2+\mathrm{A} 3}{3}$

Where:

A1 = percentages of asphalt content at maximum stability.

$\mathrm{A} 2=$ percentages of asphalt content at maximum density $(\mathrm{Gmb})$.

A3 $=$ percentages of asphalt content at specified percent of voids in compacted mixtures $\left(\right.$ VTM, $\mathrm{V}_{\mathrm{a}}$ ).

The optimum asphalt content (O.A.C) was found equal to $\mathbf{4 . 9 \%}$ by weight of the total aggregates [16].

Table (5) Marshall Properties for determination Optimum Asphalt Content*

\begin{tabular}{|l|c|c|c|c|c|}
\hline \multicolumn{1}{|c|}{ Asphalt content } & $\mathbf{4 \%}$ & $\mathbf{4 . 5 \%}$ & $\mathbf{5 \%}$ & $\mathbf{5 . 5 \%}$ & $\mathbf{6 \%}$ \\
\hline Properties & & & & & \\
\hline Marshall Stability (ASTM D 1559), (KN) & 8.264 & 9.366 & 10.422 & 9.534 & 8.043 \\
\hline Marshall Flow , (0.25mm) & 2.159 & 2.464 & 2.946 & 3.581 & 4.394 \\
\hline Bulk Specific Gravity, $\left(\mathbf{G}_{\mathbf{m b}}\right), \mathrm{gm} / \mathrm{cm}^{\mathbf{3}}$ & 2.292 & 2.331 & 2.382 & 2.312 & 2.271 \\
\hline Air Voids in Total Mix, (VTM), (V $\mathbf{a}) \%$ & 5.601 & 4.428 & 3.524 & 3.183 & 2.990 \\
\hline Air Voids in Mineral Agg. , (VMA), \% & 17.591 & 16.625 & 15.247 & 18.171 & 20.047 \\
\hline Air Voids Filled with Asphalt, (VFA), \% & 68.160 & 73.365 & 78.887 & 82.483 & 85.085 \\
\hline
\end{tabular}

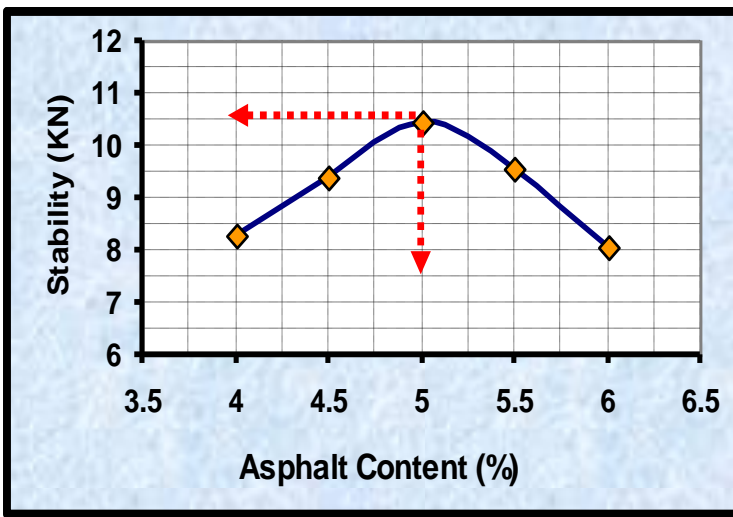

Fig.(1) The relationship between Asphalt Content and Marshal Stability.

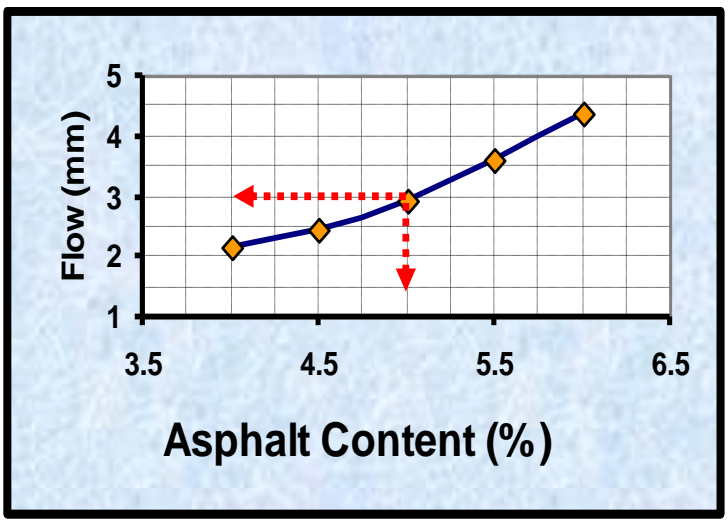

Fig.(2) The relationship between Asphalt Content and Flow. 


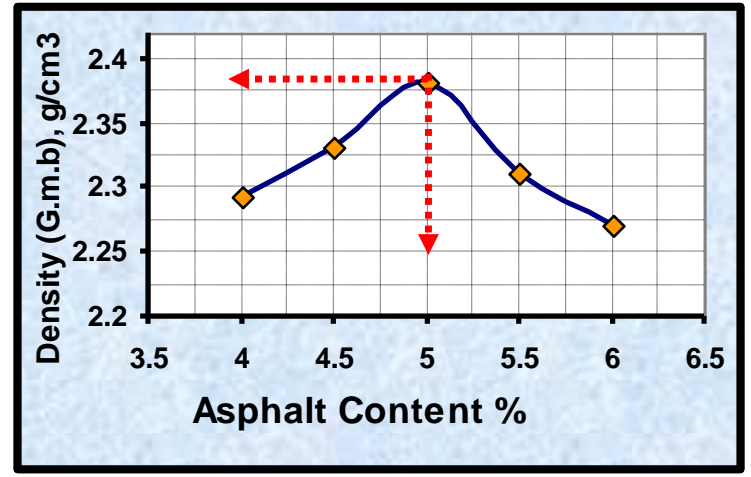

Fig.(3) The relationship between Asphalt Content and Density (Gmb)

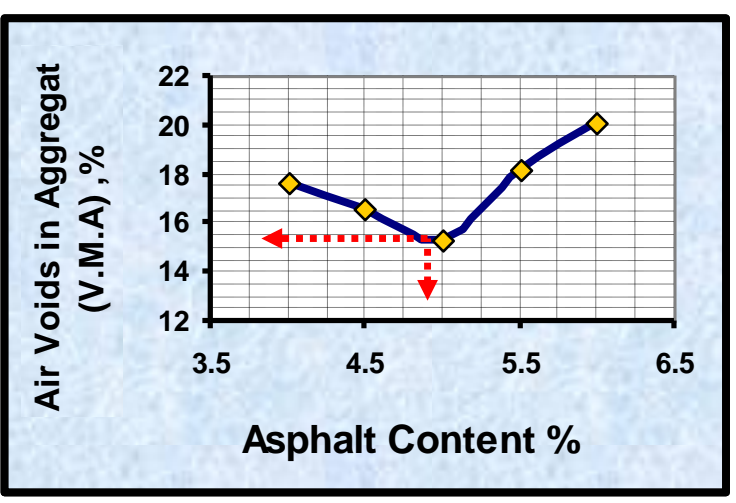

Fig.(5) The relationship between Asphalt Content and (V.M.A)

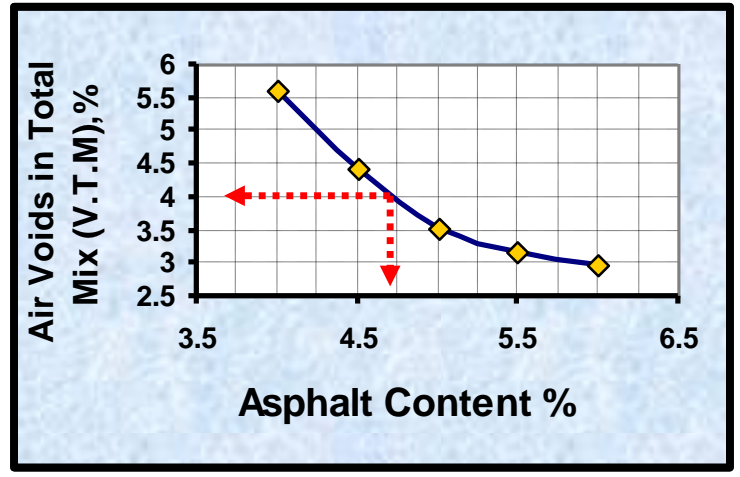

Fig.(4) The relationship between Asphalt Content and (VTM) $\left(\mathbf{V}_{\mathbf{a}}\right)$

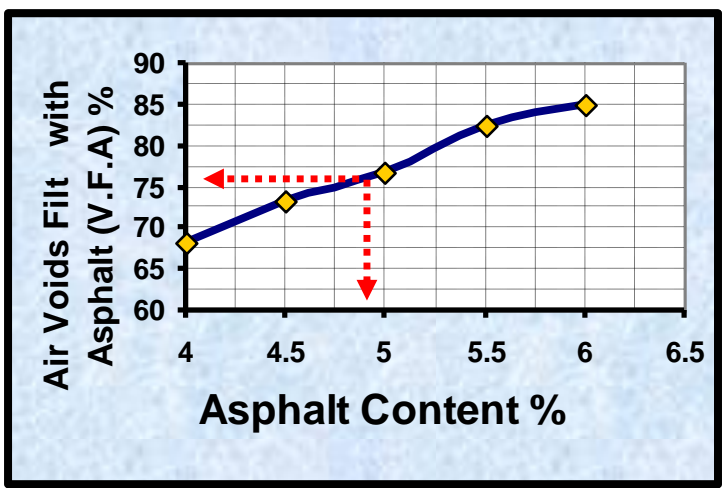

Fig (6) The relationship between

Asphalt Content and (V.F.A)

The relationships between Asphalt Content and Properties of Mixtures

\subsection{Evaluation and adjustment of the mix design:}

The overall objective of the mix design was to determine an optimum blend of different components that will satisfy the requirements of the given specifications. Table (6) shows that $4.9 \%$ of (O.A.C) was satisfied the (SORB/9).

Table (6) Marshall Properties at Optimum Asphalt Content*

\begin{tabular}{|c|c|c|}
\hline Properties & $\begin{array}{c}\text { Values at } \\
\text { O.A.C }\end{array}$ & $\begin{array}{c}\text { Specification Limits of } \\
\text { (SORB / R9) for Wearing } \\
\text { course }\end{array}$ \\
\hline Marshall Stability (ASTM D 1559), (KN) & 10.4 & $8 \mathrm{KN}$ ( min.) \\
\hline Marshall Flow, (0.25 mm) & 2.7 & $2-4$ \\
\hline Bulk Specific Gravity, $\left(\mathbf{G}_{\mathbf{m b}}\right), \mathrm{gm} / \mathrm{cm}^{3}$ & 2.380 & --------- \\
\hline Air Voids in Total Mix, $(\mathbf{V T M}),\left(\mathbf{V}_{\mathbf{a}}\right), \%$ & 3.65 & $3-5$ \\
\hline Air Voids in Mineral Agg. ,(VMA), \% & 15 & $14 \% \min$ \\
\hline Air Voids Filled with Asphalt,(VFA), \% & 76 & $60-80 \%$ \\
\hline Index Retained Strength (ASTM D1075), \% & 73 & 70 ( min.) \\
\hline Optimum Asphalt Content, (O.A.C) & 4.9 & $4-6 \%$ \\
\hline
\end{tabular}

\section{7 different contents, using the (O.A.C):}

At least, nine specimens of mixtures were prepared according (ASTM D1559) using the (O.A.C) of $4.9 \%$ asphalt weight of total aggregates and three types of fillers which were: 
ordinary portland cement, lime stone powder and glass powder with three percentages which were: $4 \%, 6 \%$ and $8 \%$ by the weight of total aggregates.

\section{Results and Discussion:}

The specimens have been laboratory tested and investigated for Marshall Properties in Roads Laboratory of Civil Engineering Dept /Mosul University, and the calculations for stability, flow, bulk density $\left(\mathrm{G}_{\mathrm{mb}}\right)$, (VTM), (V.M.A) and (V.F.A) were preformed as shown in Table (7). Then these test results were graphically drawn as shown in Figs. (7 to12).

Fig.(7) shows the relationship between filler content and Marshall Stability, the results shows that the stability is high for glass powder than ordinary portland cement and lime stone powder mixtures, and the maximum stability is attained at $6 \%$ content for lime stone powder and glass powder mixtures .

Fig.(8) shows the relationship between filler content and Marshall Flow, the results show that the values of flow for all mixtures were acceptable values as compared were with the specification limits. Also the results show that the values of flow were increased for ordinary portland cement and lime stone powder when the filler content increased too, while the values of flow for glass powder were decreased.

Fig.(9) shows the relationship between filler content and Bulk Density $\left(G_{m b}\right)$,the results show that the values of density were increased for ordinary portland cement and lime stone powder as filler content increased, while the values of density for glass powder were decreased. The results reveal slight differences in density values, which depend upon the specific gravity of each filler. The results indicated that the values of density for ordinary portland cement and lime stone powder mixtures increased from 2.256 and $2.218 \mathrm{gm} / \mathrm{cm}^{3}$ at $4 \%$ of filler content to 2.289 and $2.270 \mathrm{gm} / \mathrm{cm}^{3}$ at $8 \%$ of filler content respectively. While decreased for glass powder from $2.26 \mathrm{gm} / \mathrm{cm}^{3}$ at $4 \%$ content to $2.238 \mathrm{gm} / \mathrm{cm}^{3}$ at $8 \%$ of filler content.

Fig. (10) and Fig. (11) Both show the relationships between filler content and \% of Air Voids in Mix (VTM) and \% of Air Voids in Minerals (V.M.A). The results show that the values of (VA) and (V.M.A) were decreased for ordinary portland cement and lime stone powder with increment of the filler content, while for glass powder were increased .

Fig.(12) shows the relationship between filler content and \% of air voids filled with Asphalt (V.F.A), the results show that the values of (V.F.A) were increased for ordinary portland cement and lime stone powder as filler content is increased, while the values of (V.F.A) for glass powder were decreased as the filler content is increased .

The results of this study show that the use of glass powder as a filler at $8 \%$ is the best among the three types of filler that used according to the tests results and figures ( 7 to 12).

The values of Flow and (V.M.A) were closely within the specification limits of (SORB/ 9).

\section{Conclusions:}

The theoretical and experimental results of this study can be summarized as follow: 1-Adding glass powder of $6 \%$ by total weight of aggregates on the hot asphalt concrete mixtures leading to increase the Marshall stability by $15.5 \%$ and $9.2 \%$ compared with ordinary portland cement and lime stone powder respectively. While, the Flow decreases by $14.5 \%$, and increased by $4.4 \%$ compared with ordinary portland cement and lime stone powder respectively. 


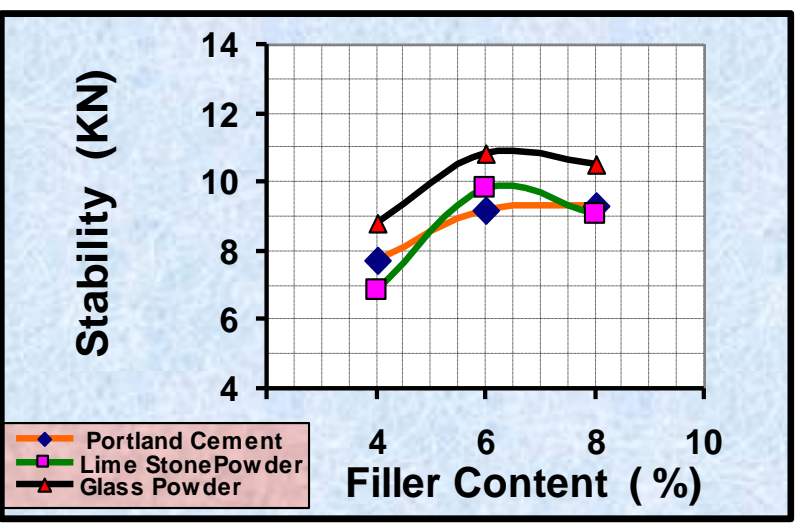

Fig.(7) The relationship between Filler Content and Marshal Stability

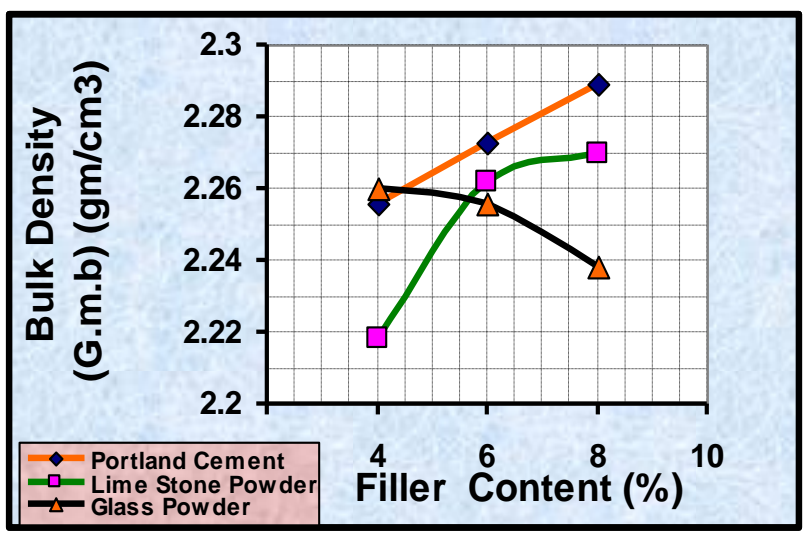

Fig.(9)The relationship between Filler Content and Density (Gmb)

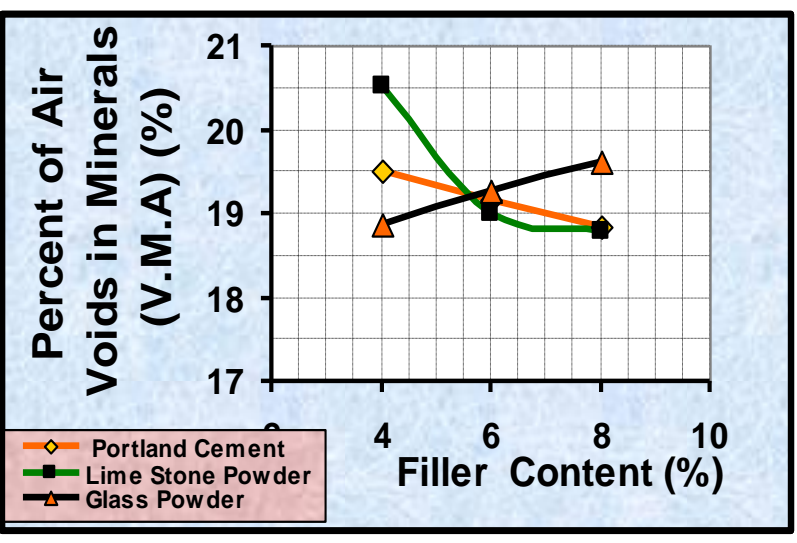

Fig.(11) The relationship between Filler Content and (V.M.A)

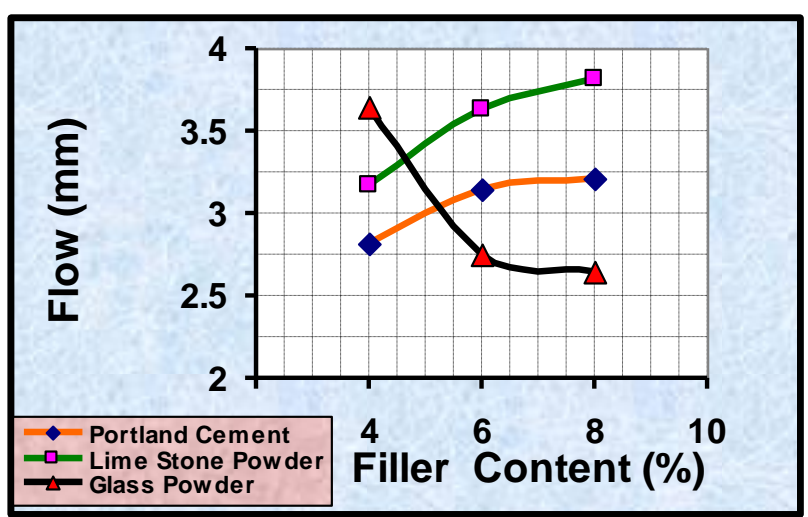

Fig.(8) The relationship between Filler Content and Flow.

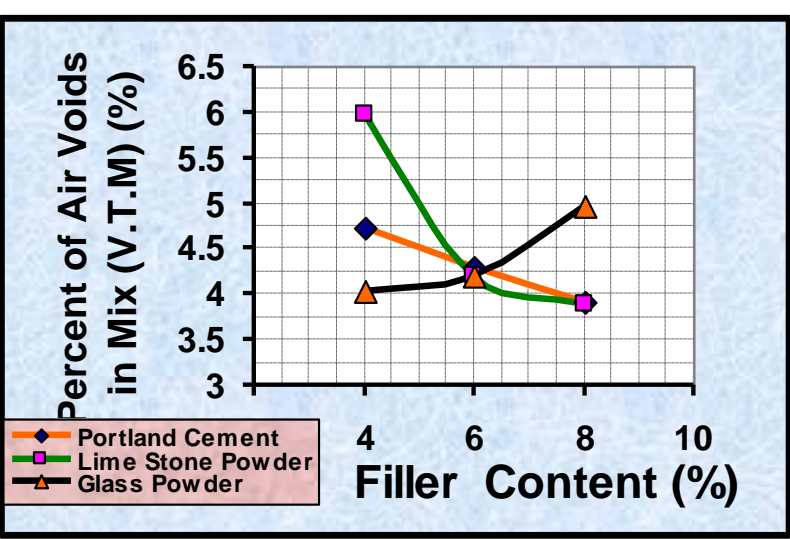

Fig.(10) The relationship between Filler Content and $(\mathbf{V T M}),\left(\mathbf{V}_{\mathbf{a}}\right)$

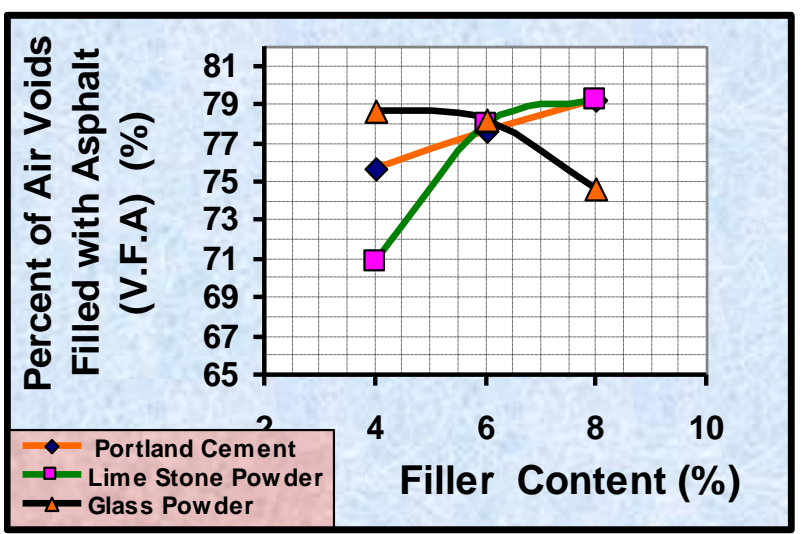

Fig.(12) The relationship between Filler Content and (V.F.A)

The relationships between Filler Content and Properties of Mixtures 
2- Adding glass powder of $8 \%$ by total weight of aggregates on the hot asphalt concrete mixtures leading to increase the Marshall stability by $11.7 \%$ and $14.3 \%$ compared with ordinary portland cement and lime stone powder respectively. While, the Flow decreased by $21.6 \%$ and $44.3 \%$ compared with ordinary portland cement and lime stone powder respectively.

3-The(VTM) and (V.M.A) decreased as the percentage of ordinary portland cement and lime stone powder increase, and (V.F.A)increased as the percentage of glass powder decreased.

Tale (7) Marshall Properties for Different Type and percent of fillers at O.A.C *

\begin{tabular}{|c|c|c|c|c|c|c|c|}
\hline Properties & $\begin{array}{c}\% \text { of } \\
\text { Filler by } \\
\text { total } \\
\text { weight of } \\
\text { mix }\end{array}$ & $\begin{array}{c}\text { Stability } \\
\text { (KN) }\end{array}$ & $\begin{array}{l}\text { Flow } \\
(0.25 \\
\text { mm) }\end{array}$ & $\begin{array}{c}\text { Bulk } \\
\text { Density } \\
\text { G }_{\mathbf{m b}} \\
\left(\mathrm{gm} / \mathrm{cm}^{3}\right)\end{array}$ & $\begin{array}{c}\% \text { of } \\
\text { Voids in } \\
\text { Total Mix } \\
(\text { VTM) } \\
\left(V_{a}\right)\end{array}$ & $\begin{array}{c}\text { \% of Air } \\
\text { Voids in } \\
\text { Mineral } \\
\text { Agg. } \\
\text { (V.M.A) }\end{array}$ & $\begin{array}{c}\% \text { of Air } \\
\text { Voids Filled } \\
\text { with } \\
\text { Asphalt } \\
\text { (V.F.B) }\end{array}$ \\
\hline \multirow{3}{*}{$\begin{array}{l}\text { Ordinary } \\
\text { Portland } \\
\text { Cement }\end{array}$} & $4 \%$ & 7.71 & 2.81 & 2.256 & 4.730 & 19.495 & 75.737 \\
\hline & $6 \%$ & 9.16 & 3.15 & 2.273 & 4.295 & 19.161 & 77.585 \\
\hline & $8 \%$ & 9.32 & 3.21 & 2.289 & 3.904 & 18.835 & 79.272 \\
\hline \multirow{3}{*}{$\begin{array}{l}\text { Lime Stone } \\
\text { Powder }\end{array}$} & $4 \%$ & 6.87 & 3.17 & 2.218 & 5.977 & 20.523 & 70.877 \\
\hline & $6 \%$ & 9.84 & 3.63 & 2.262 & 4.193 & 19.007 & 77.940 \\
\hline & $8 \%$ & 9.04 & 3.81 & 2.270 & 3.895 & 18.782 & 79.262 \\
\hline \multirow[t]{3}{*}{ Glass Powder } & $4 \%$ & 8.80 & 3.64 & 2.260 & 4.034 & 18.865 & 78.616 \\
\hline & $6 \%$ & 10.84 & 2.75 & 2.256 & 4.204 & 19.260 & 78.172 \\
\hline & $8 \%$ & 10.55 & 2.64 & 2.238 & 4.968 & 19.625 & 74.685 \\
\hline
\end{tabular}

\section{Recommendations:}

The following recommendations may be suggested for further works:

1- The research was done using one type of petroleum asphalt cement (brought from Bagee fj Refinery) with grade 40/50 Penetration. It is therefore, recommended to do other studies on different source of petroleum asphalt cement, or with different grade of petroleum asphalt.

2- Applying the Tensile Strength Test, i.e. "Resistance of Compacted Asphalt Mixtures to Moisture- Induced Damage according to (AASHTO T 283) ${ }^{(17) " ~ o n ~ c o m p a c t e d ~ s p e c i m e n s ~ o f ~}$ mixtures.This test can be used to determine if the materials used was subject to stripping by measuring the force required to pull apart a material. This test may also be performed on cores taken from the finished pavement.

3-Studying the effect of using glass powder as filler in asphalt mixtures on flexural strength under repeated load.

4- From an economical view point, studying should be taken on a lot of local waste materials might be used as mineral fillers for asphalt mixtures, such as brick dust ,steel fibers, iron filing, polymers etc.,

\section{References:}

1. Tunnicliff D.G., “A Review of Mineral Filler”, A.A.P.T. Vol. 3, 1962.

2. Harris B.M. and Stuart K.D., "Analysis of mineral fillers and mastics used in stone matrix asphalt", J. Assoc. Asphalt Paving Technol. , 1995. 
3. Ratnasamy M., Eltaher A., The effect of type and particle size of industrial wastes filler on Indirect Tensile Stiffness and Fatigue performance of S.M.A. Mixtures " Australian

4. State Organization of Roads, and Bridges Specifications ( SORB /R9), Chapter 9, 2003

5. Al-Sayed, M.H.,"The Effect funeral filler performance of tolled Asphaltic Mixes", Ph.D. Thesis, University of Leeds, 1988.

6. Harrigan E.T. , "Research Results Digest" , N.C.H.R.P. ,2011 .

7. Csanyi L. H., Cox R. and Teagle C.R. , "Effect of fillers on Asphaltic Concrete Mixes", HRB, No.51, 1964.

8.Al-Qaisi T.A., "The Effect of Mineral Filler on the Asphalt Paving Mixtures", M.Sc. Thesis, College of Engineering, University of Baghdad, 1981.

9. Sofia G.G. "The Effect of Dust Fines on the Properties of Asphalt Paving Mixtures", M.Sc. Thesis, College of Engineering, University of Mosul, 1986.

10. Sadoon O.E. , " The influence of Filler Type on Asphalt Mastic and Performance Properties of Asphalt Paving Materials" ,M.Sc Thesis, College of Engineering , University Anbar, 2010.

11. American Association of State Highway and Transportation Officials (AASHTO), "standard specification for materials for aggregate and soil- aggregate sub base ,base and surface courses " ,1965.

12. The Asphalt Institution, " The Asphalt Handbook ", 1962

13. American Society for Testing and Materials (ASTM D 1559-89), " Test Method for Resistance of Plastic Flow of Bituminous Mixtures Using Marshall Apparatus", Annual Book of ASTM Standards section 4 Vol. 04-03, Philadelphia 1994.

14. Multi -Regional Asphalt Training and Certification Group, "Hot Mix Asphalt Technician Training Manual", 2006.

15. Office of Flexible Pavement Materials, Department of Transportation," Determination of Theoretical Maximum Specific Gravity of Mixtures with Different Asphalt Contents" , California 2004.

16. Asphalt Institute Manual Series (MS-2), "Marshall Methods for Asphalt concrete and hot mix types ", Lexington KY 1993.

17. Bulk Specific Gravity of Compacted Bituminous Mixtures Using Saturated Surface - Dry Specimens, AASHTO T166, 2000.

18. WSDOT Materials Manual, "Theoretical Maximum Specific Gravity and Density of Bituminous Paving Mixtures", AASHTO T209, 2011.

19. Tx DOT Designation, "Test Procedure for Theoretical Maximum Specific Gravity of Bituminous Mixtures", 2008.

21. RobertY.L. , "Refine AASHTO T283 Resistance of Compacted Bituminous Mixture to Moisture Induced Damage”, U.S Transportation Department, 2008.

22. Richard C.M., " Effects of Aggregate and Mineral Fillers on Asphalt Mixture Performance", ASTM, Philadelphia, 1992.

23. Meyer W.E. and Reichert J., "Surface Characteristics of Roads", ASTM, 1990.

The work was carried out at the college of Engineering. University of Mosul 